\title{
A stand-level tool for predicting the natural regeneration density of black spruce and jack pine following fire and salvage
}

\author{
by T.B. Splawinski ${ }^{1, *}$, D.F. Greene ${ }^{2}$, S. Gauthier ${ }^{3}$ and Y. Bergeron ${ }^{4}$
}

\begin{abstract}
A tool was developed to allow managers and foresters to quickly assess reforestation needs following forest fire and salvage logging at the stand level in both pure and mixed black spruce and jack pine stands. This on-site operational assessment tool was created using a forest regeneration model that simulates the natural regeneration densities of black spruce and jack pine following fire and salvage. Tree species basal areas used for simulations represent the natural range expected in the field. Additional parameters include the abscission schedule of the species, the percentage of optimal (exposed mineral soil or humus) post-fire seedbeds, and the timing of the salvage operation. The tool also allows for rapid planning of both salvage operations and planting. It has important advantages over conventional seedling surveys in that it can be employed immediately following fire, can guide management decisions about the planning of road construction and the harvest sequence, and takes into account the entire establishment phase. Using the tool to adjust the harvesting schedule to minimize replanting, the likely final cost of reforestation can be estimated for an entire burn. The tool shows that a higher percentage of optimal seedbeds are necessary following salvage: (1) for black spruce to regenerate adequately compared to jack pine (i.e., planting of black spruce will almost always be necessary); (2) as basal area of the species of interest decreases; and, (3) to adequately regenerate burned intact and salvaged stands in late-season fires compared with those from early-season fires.
\end{abstract}

Keywords: fire, salvage, black spruce, jack pine, natural regeneration, model, planting, stand-level assessment.

\section{RESUMÉ}

Un outil a été élaboré afin de permettre aux gestionnaires et aux forestiers dévaluer rapidement les besoins en matière de régénération des peuplements ravagés par le feu et exploité peu après, tant dans le cas des pessières noires pures et mélangées que dans le cas des pinèdes grises. Cet outil dévaluation utilisable sur place a été élaboré à partir d'un modèle de régénération forestière qui simule les densités de régénération naturelle des pessières noires et des pinèdes grises à la suite d'un feu et des travaux de récupération. Les surfaces terrières des arbres utilisées lors des simulations sont représentatives de la variation naturelle retrouvée dans la nature. Des paramètres supplémentaires comme le délai d’abscission des espèces, le pourcentage de lits propices à la germination (sol minéral exposé ou humus) et le calendrier des opérations de récupération ont été ajoutés au modèle. L'outil permet également la planification rapide des opérations de récupération et de plantation. Il constitue un avantage important relativement aux inventaires conventionnels de semis du fait qu'il peut être utilisé immédiatement après un feu, qu'il permet de guider la gestion des décisions reliées à planification de la construction des chemins et à la séquence des opérations de récolte, en plus de prendre en considération lensemble de la réalisation des opérations. L’emploi de loutil pour ajuster le calendrier de récolte dans le but de minimiser les coûts de reboisement, permet également d'estimer les coûts totaux de reboisement pour lensemble d'une superficie ravagée par le feu. L’outil indique qu'un plus fort pourcentage de lits propices à la germination est requis à la suite des opérations de récupération suivantes : (1) pour la régénération adéquate des pessières par comparaison aux pinèdes grises (par ex., la plantation dépinettes noires sera presque toujours nécessaire); (2) dans le cas où la surface terrière des espèces recherchées est faible; et (3) pour régénérer adéquatement les peuplements ravagés par le feu laissés tel quel et ceux récupérés à la fin de la saison des feux de forêts comparativement à ceux ayant été ravagés au début de la saison des feux.

Mots clés : feu, récupération, épinette noire, pin gris, régénération naturelle, modèle, reboisement, évaluation du peuplement sur place

\footnotetext{
${ }^{1}$ Centre for Forest Research, Université du Québec à Montréal, Pavillon des Sciences biologiques (SB), 141 avenue du Président-Kennedy, Montreal, Quebec, Canada H2X 1Y4. *Corresponding author. e-mail: tsplawinski@gmail.com

${ }^{2}$ Department of Forestry and Wildland Resources, Humboldt State University, 1 Harpst Street Arcata, California, United States, 955218299. E-mail: David.Greene@humboldt.edu

${ }^{3}$ Natural Resources Canada, Canadian Forest Service, Laurentian Forestry Centre, 1055 rue du PEPS, P.O. Box 10380, Stn. Sainte Foy, Quebec, Canada G1V 4C7. E-mail: sylvie.gauthier@rncan-nrcan.gc.ca

${ }^{4}$ Centre d'étude sur la forêt and Chaire industrielle en aménagement forestier durable, Université du Québec à Montréal, CP 8888 Succursale A, Montréal, Quebec, Canada H3C 3P8. E-mail: bergeron.yves@uqam.ca
} 


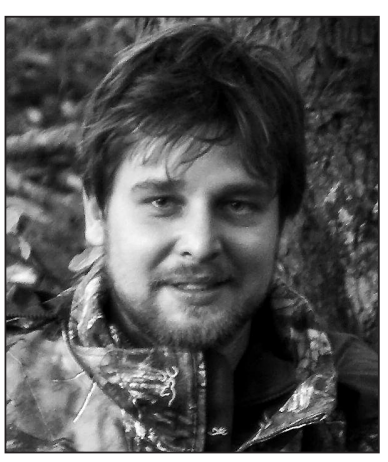

T.B. Splawinski

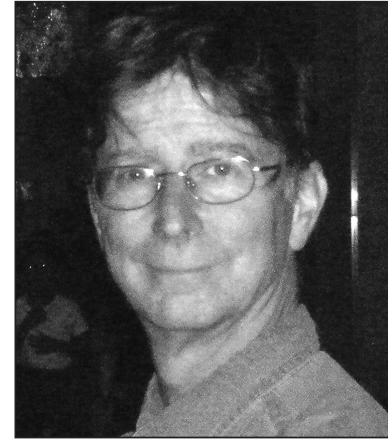

D.F. Greene

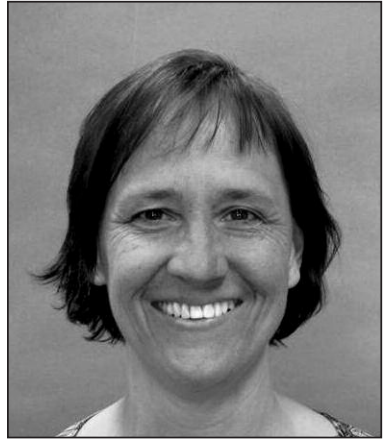

S. Gauthier

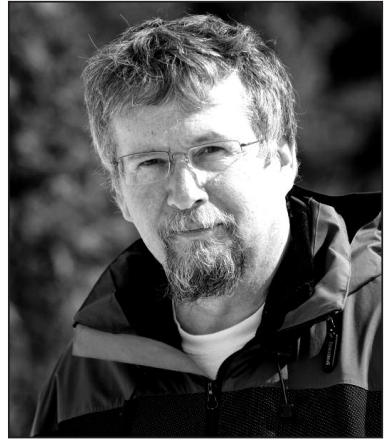

Y. Bergeron

\section{Introduction}

Black spruce (Picea mariana (Mill.) BSP) and jack pine (Pinus banksiana Lamb.) are the two most common conifers in Canada (Greene et al. 1999), and are well-adapted to the stand-replacing wildfires common to the circumboreal forest because of their aerial seedbanks, i.e., canopy seed storage (Enright et al. 1998, Greene et al. 1999, Stocks et al. 2002, De Groot et al. 2004). The passage of the flaming front results in the opening of scales on the cones, thus allowing seeds to abscise (Lamont et al. 1991, Enright et al. 1998, Johnstone et al. 2009, Greene et al. 2013). These seeds are then dispersed onto organic layers that have been reduced by smoldering combustion following medium to high severity fires, with about $40 \%$ of the substrate on average rendered into optimal seedbeds of a few centimetres organic thickness or less (Miyanishi 2001, Miyanishi and Johnson 2002, Greene et al. 2007). At times, conifer recruitment can be low following low severity fire due to fewer suitable seedbeds as less organic matter is removed (Veilleux-Nolin and Payette 2012), and by lower availability of seeds (Lecomte et al. 2006).

The abscission period for black spruce seeds is more protracted than for jack pine, requiring roughly five years to abscise $90 \%$ of seeds compared to about one year for jack pine (Greene et al. 2013). Salvage operations are typically scheduled within the first few months following fire to minimize degradation of fire-killed boles by saprophagous beetle larvae and by checking (St-Germain and Greene 2009). The removal of these stems effectively removes the non-abscised portion of the aerial seedbank (Greene et al. 2006, 2013; Splawinski et al. 2014), and the operation also leads to dramatic mortality among the first cohort of germinants. This has a negative effect on black spruce, and to a far lesser extent jack pine, regeneration potential (Greene et al. 2006, 2013; Splawinski et al. 2014). Stands that exhibit poor stocking following salvage must be planted at a cost of about CAD $\$ 800 /$ ha (St-Germain and Greene 2009).

With the exception of seedling surveys, managers and foresters currently do not possess stand-level tools to assess reforestation needs following fire and salvage in both pure and mixed black spruce and jack pine stands. The conventional seedling survey is often carried out in the first year or two following fire, and therefore cannot take into account subsequent recruitment. Thus it is not possible to rapidly make decisions about which areas within a recent burn will likely need to be planted. An on-site assessment tool capable of identifying reforestation needs immediately after the fire should reduce the planning time of both salvage operations and subsequent planting, and can save money on replanting. Further, it can show the manager the percentage of stands that would have acceptable stocking levels if the salvage was delayed for a specified period.

The objective of this paper, therefore, is to develop an operational tool using the Splawinski et al. (2014) regeneration model that will permit estimation of natural regeneration densities of black spruce and jack pine following moderate to severe fire, either early or late in the growing season, followed by salvage logging. Here we define moderate to severe fires as those that result in $100 \%$ tree mortality within a stand and not the intensity of the fire itself. This objective will be accomplished by identifying the proportion of good seedbeds required to obtain adequate stand stocking under a range of expected pre-fire basal areas. As examples of model output, we produce four figures, two of which illustrate simulation results, and two (the assessment tool itself) that can be used in the field by foresters in a fresh burn, perhaps as laminated cards that fit in a shirt pocket for easy use or on a smartphone.

\section{Materials and Methods}

Splawinski et al. (2014) developed a regeneration model capable of simulating the natural regeneration densities (seedlings $/ \mathrm{m}^{2}$ ) of black spruce and jack pine following fire and salvage at the stand level during the establishment phase (the first six years post-fire). The main parameters are: (1) initial seed availability, computed as a function of source tree basal area, seed survival through the passage of the flaming front, and salvage proportion; (2) seed abscission as a function of time since fire; (3) seedling survivorship as a function of seed mass (germinant size), seedbed proportion, and granivory; (4) the timing of salvage operation; and, (5) seedling and seed mortality as a function of salvage operations.

Detailed information on the parameterization and limits of the model are available in Splawinski et al. (2014). Briefly, the model uses three types of seedbed classes in simulations: good, poor, and lethal. Each seedbed class is characterized by a single survivorship value. The good-seedbed category is subdivided into exposed mineral soil and living mosses (feathermoss and Sphagnum), while the poor-substrate category includes lichens, burnt or residual duff, and thick layers of unburnt leaves or dead mosses. Finally, the lethal-seedbed category includes firm but non-burnt logs, charred logs, rocks, and standing puddles. An average lethal-seedbed proportion of $10 \%$ was obtained from four wildfires: the same 
Table 1. Power law regression results for observed versus simulated seedling densities [seedlings $/ \mathrm{m}^{2}$ ] from Splawinski et al. (2014)

\begin{tabular}{lllcccc}
\hline Fire & Species & Treatment & Intercept & Slope & $\mathbf{r}^{2}$ & $n$ \\
\hline $\begin{array}{l}\text { Lebel-sur-Quevillion } \\
\text { (Quebec) }\end{array}$ & P. mariana & Lumped & 0.225 & 1.308 & 0.920 & 6 \\
& & & & & \\
Val Paradis & P. mariana & Intact & -0.477 & 0.639 & 0.325 & 16 \\
(Quebec) & Salvaged & $-2.541^{*}$ & $0.018^{*}$ & 0.000 & 19 \\
& P. banksiana & Intact & 0.06 & 0.062 & 0.003 & 10 \\
& & Salvaged & 0.053 & 1.271 & 0.423 & 17 \\
Muskeg & & & & & \\
(Saskatchewan) & P. mariana & Intact & $0.841^{*}$ & 0.978 & 0.567 & 18 \\
\hline
\end{tabular}

Note: For intercept or slope values, ${ }^{*}$ represents a significant difference from 0 and 1 respectively.

$100 \%$ salvaged stands. Moreover, an early and a late season fire are examined. First, a June fire date was used, since late spring/early summer represents the period of most frequent fire occurrence in the Canadian boreal forest (Stocks et al. 2002). Second, an August fire date was used, as this month represents the late fire season (Stocks et al. 2002).

These fire dates were also selected to illustrate the potential differences in seed predation following early and late-season fires. Based on the limited granivory data currently available for the boreal forest, the Splawinski et al. (2014) regeneration model assumes that $5 \%$ of seeds will

three used for model validation in Splawinski et al. (2014), as well as unpublished data from the 2010 La Tuque wildfire (northwestern Quebec). In this approach, if the goodseedbed proportion is increased, the poor-seedbed proportion is decreased accordingly, while the lethal proportion always remains constant at $10 \%$.

The post-fire regeneration model was validated using field data obtained from three fires, two in Quebec and one in Saskatchewan. Log-transformed regressions were performed on observed versus simulated seedling densities of black spruce and jack pine, for all fires and treatments, to determine if the intercept was significantly different from 0 and slope significantly different from 1 . Results of the analysis are in Table 1.

A sensitivity analysis was also performed, indicating that the model is most sensitive to seed mortality resulting from the passage of the flaming front and the post-fire granivory rate. It assumes a 53\% seed survival rate following the passage of the flaming front for black spruce and a $100 \%$ survival rate for jack pine (Greene and Johnson 1999, De Groot et al. 2004). There is a relative lack of empirical data on post-fire granivory rates. However, based on two studies (Greene and Johnson 1998, Charron and Greene 2002), the survivorship through the granivory stage is estimated at $95 \%$ for the summer of the fire itself and is subsequently reduced to $43 \%$ for the reminder of the simulation (Splawinski et al. 2014).

\section{Prescriptive simulations}

Unlike Splawinski et al. (2014), here we examine the minimal proportion of good seedbeds required to yield one seedling $/ \mathrm{m}^{2}$ across a range of basal areas under an early and late season fire date. In conifer plantations, trees are typically spaced approximately two metres apart to minimize competition, thereby increasing growth and volume (Zhang et al. 2002); however stems in naturally established stands tend to be distributed heterogeneously. Clumping is often observed on good seedbeds (which make up a relatively low proportion of total seedbeds), whereas poor seedbeds will exhibit lower densities (Greene et al. 2006, Splawinski et al. 2014). Therefore a seedling density of $-1 / \mathrm{m}^{2}(10,000 / \mathrm{ha})$ or greater is considered adequate to re-stock a naturally regenerated stand (Greene et al. 2002).

Two scenarios were simulated: (1) regeneration density of black spruce and jack pine in burnt intact stands; and, (2) in be consumed during the summer of the fire, after which the rate will rise to $57 \%$ for the remainder of the simulation. This is based on the argument that medium to high severity fires will greatly reduce granivore populations, with a significant amount of time necessary (at least four months) before they are able to re-establish (Splawinski et al. 2014). Thus the earlier the fire, the more time the first cohort has to establish under a lower granivory rate; conversely the later the fire, the more seeds will end up germinating in the second cohort under a higher granivory rate.

A December salvage date is used for both fire dates as this month represents the median salvage month observed in the Lebel-sur-Quevillon wildfire (Splawinski et al. 2014). Simulations are carried out for pre-fire basal areas ranging from $5 \mathrm{~m}^{2} /$ ha to $50 \mathrm{~m}^{2} / \mathrm{ha}$, in increments of 2.5 . This represents the range of basal areas expected in the field as observed in the temporary plot data of the Quebec Ministry of Forests, Wildlife and Parks in the boreal forest of northwestern Quebec (Lake Matagami lowland ecological region 6a). This ecological region is delimited using a hierarchical ecological classification system, with territories sub-divided based on ecological factors (Blouin and Berger 2005). For every increment of basal area, the percentage of good-seedbeds that will yield $\geq$ one seedling $/ \mathrm{m}^{2}$ is identified. Although the model simulates seedlings $/ \mathrm{m}^{2}$, and the basal area parameter is in $\mathrm{m}^{2} / \mathrm{m}^{2}$, both are converted to seedlings/ha and $\mathrm{m}^{2} /$ ha respectively, as this represents the standard used by foresters in the field.

\section{Results and Discussion}

Following fire in intact stands, a unsalvaged black sprucedominated stand with $\sim 20 \mathrm{~m}^{2} /$ ha basal area for spruce will exhibit adequate stocking ( 1 seedling $\left./ \mathrm{m}^{2}\right)$ as long as the goodseedbed category has $\geq 9 \%$ coverage following a June fire (Fig. 1a) or, 10\% coverage following an August fire (Fig. 1b). A jack pine-dominated stand with the same basal area $\left(20 \mathrm{~m}^{2} / \mathrm{ha}\right)$ should always achieve adequate stocking if the substrates in the good-seedbed category are $\geq 4 \%$ of the total following a June fire (Fig. 2a). However, following an August fire in jack pine, good seedbeds must comprise $\geq 6 \%$ of the total (Fig. 2b). This inter-specific difference is due to the shorter abscission schedule of jack pine, where $50 \%$ of seeds are abscised within roughly a month following fire, compared to 10 months for black spruce (Greene et al. 2013; Splawinski et al. 2014). As for the differences between early and late fires 

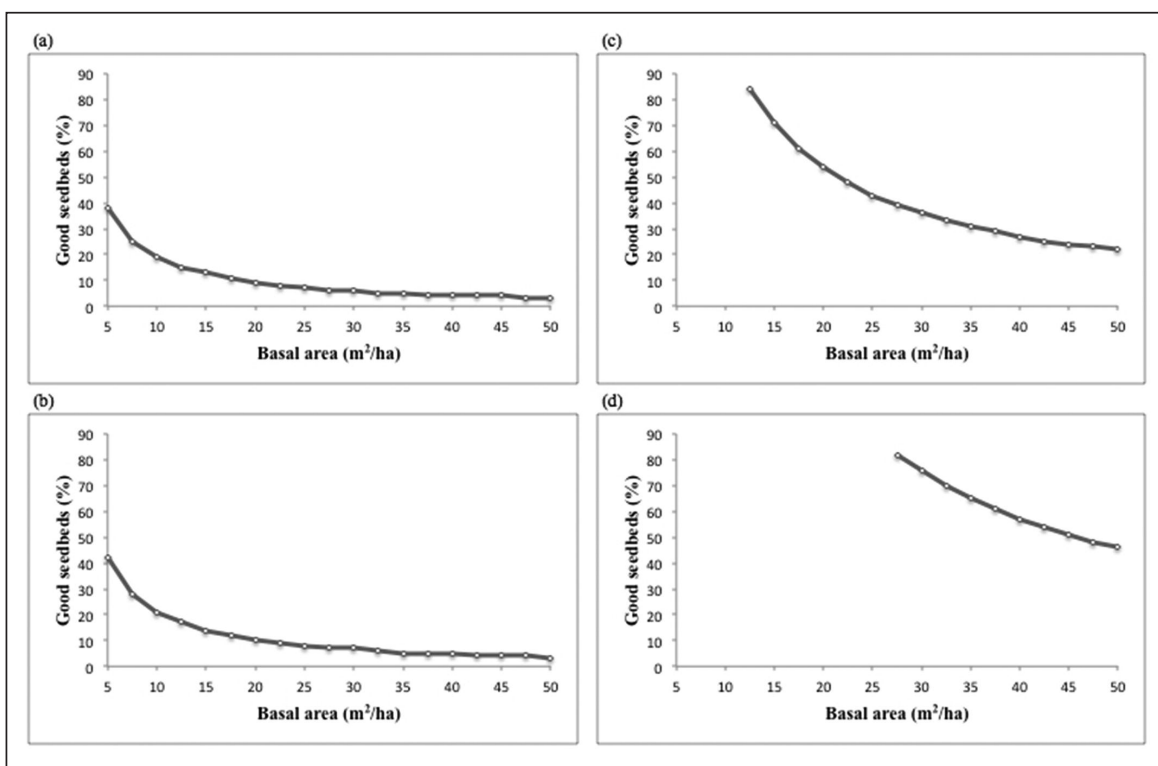

Fig. 1. Simulated percentage of good seedbeds needed for sufficient stocking according to different pre-fire basal areas for black spruce in a burned intact stand following a June (a) and August (b) fire, and a 100\% salvaged stand following a June (c) and August (d) fire. Line represents the minimum stand-stocking threshold of one seedling $/ \mathrm{m}^{2}$.
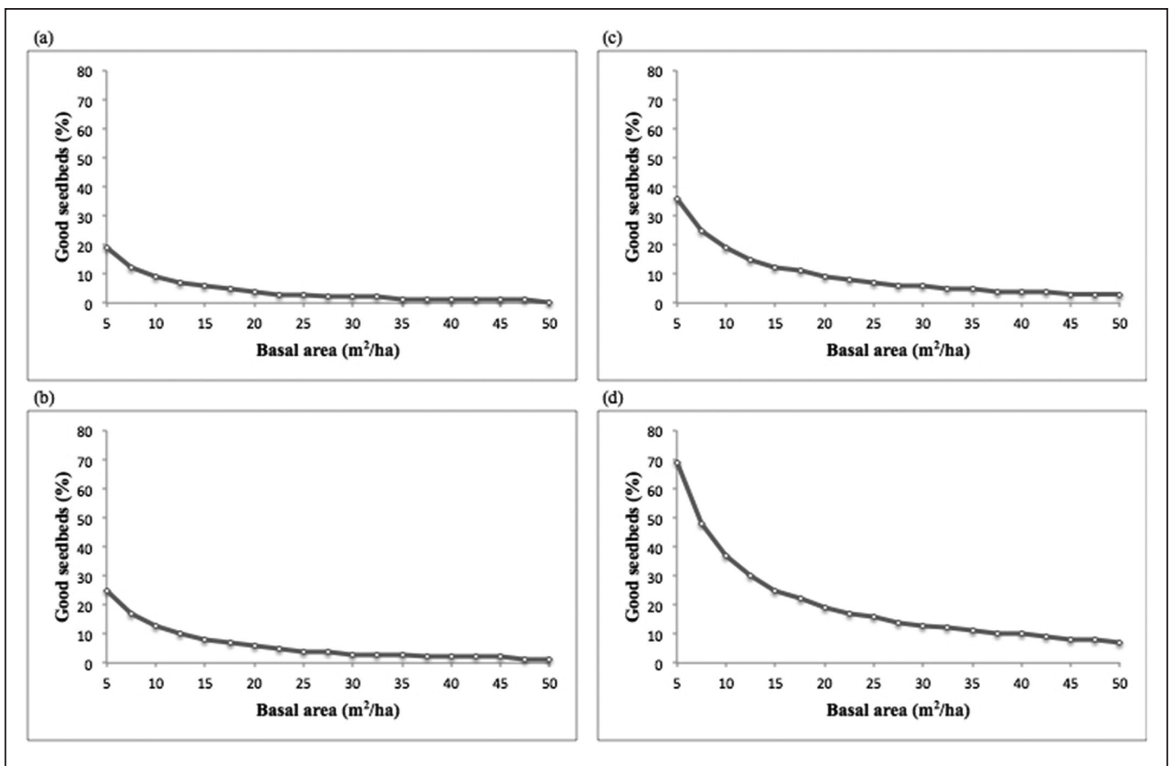

Fig. 2. Simulated percentage of good seedbeds needed for sufficient stocking according to different pre-fire basal areas for jack pine in a burned intact stand following a June (a) and August (b) fire, and a 100\% salvaged stand following a June (c) and August (d) fire. Line represents the minimum stand-stocking threshold of one seedling $/ \mathrm{m}^{2}$. ter through smoldering combustion; this is primarily due to lower duff moisture content (Kasischke et al. 2000a, 2000b; Miyanishi 2001). This may offset to some degree the increased seed losses to granivores. Of course, for either species, as the percentage of good seedbeds rises, the required basal area (directly proportional to local seed supply) for adequate regeneration declines.

As argued by Splawinski et al. (2014) and supported by the empirical literature, the largerseeded jack pine should establish at higher rates than black spruce on un-salvaged, burnt sites. Further, jack pine tends to occupy sites that have a thinner organic layer prior to the burn and a much higher proportion of good seedbeds after the fire (Greene et al. 2007). Generally, while Greene et al. (2007) found an average of $40 \%$ post-fire coverage of good seedbeds in the boreal forest, that value was much greater for pine (drier sites) than black spruce (wetter sites), and much higher in western Canada than in the more humid east. This was further supported by observations made by Greene et al. (2006) and Splawinski et al. (2014) in northwestern Quebec. Based on this, an estimated good-seedbed proportion of $27 \%$ was calculated and subsequently used by Splawinski et al. (2014) in the exploratory simulations. In the absence of salvage, therefore, we expect pure pine stands to reliably replace themselves, and mixed stands to increase their proportion of pine ( $c f$. Greene and Johnson 1999). For black spruce however, regeneration adequacy will depend very much on post-fire seedbed quality and can be problematic even if basal area is high. This constraint ultimately is due to the fact that spruce has more demanding mentioned earlier, granivory rates increase substantially (from 5\% to 57\%) following the summer of the fire (Splawinski et al. 2014). Thus following a June fire, jack pine will have the entire summer to establish its first cohort under a relatively low granivory rate (5\%). However following an August fire, pine will only have one month to establish before germination ceases due to the end of the growing season. The remaining seeds will be subjected to a higher granivory rate (57\%).

Fires occurring later in the fire season have the potential to produce greater proportions of favorable seedbeds than those occurring in the spring by removing more organic mat- seedbed requirements due to its small seeds; further, it typically occupies sites with such thick pre-fire organic layers that exposure of mineral soil by smoldering combustion is quite rare. Sphagnum, typically found on wetter sites and considered a good seedbed for germination as it remains wet during short droughts, is actually a poor medium for subsequent growth due to its relatively low nutrient supply (Lavoie et al. 2007). Therefore, sites that exhibit high post-fire proportions of sphagnum may require planting (Lavoie et al. 2007).

If $100 \%$ salvage is employed in the first winter following a June fire, black spruce will need to be planted if the basal area 

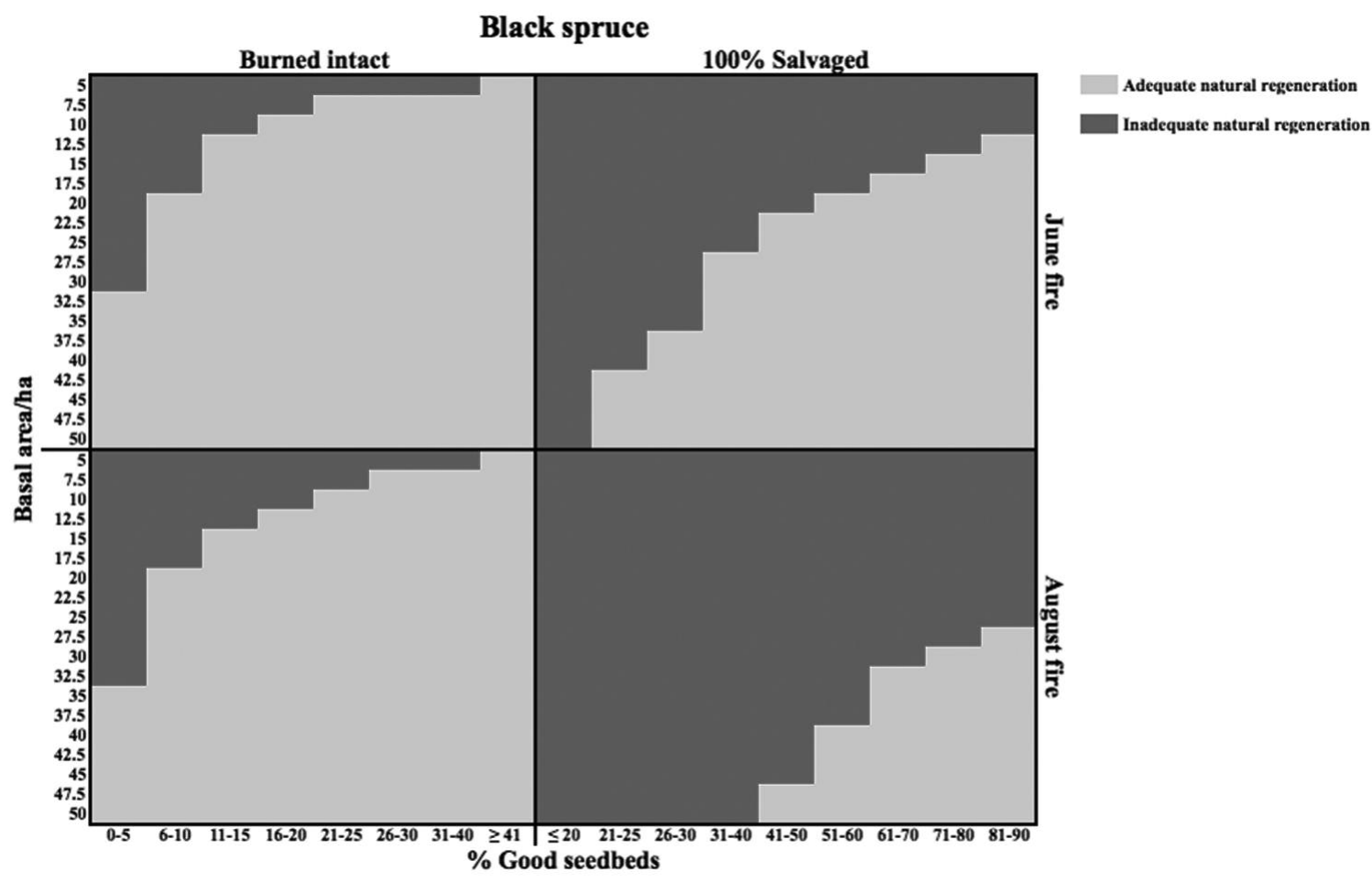

Fig. 3. Simulated black spruce natural regeneration assessment tool illustrating percent of good seedbeds needed to obtain the adequate stand stocking threshold of one seedling $/ \mathrm{m}^{2}$ for every increment of basal area, under both scenarios and fire dates.

is $\leq 40 \mathrm{~m}^{2} /$ ha with good seedbeds comprising $27 \%$ of the total (Fig.1c). Following 100\% salvage in the first winter after an August fire, black spruce will need to be planted no matter what the seed source strength (Fig. 1d). For example, even with $35 \mathrm{~m}^{2} / \mathrm{ha}$ of basal area for spruce, good-seedbed coverage of $\geq 65 \%$, which is a very unrealistic value for sites dominated by this species, would be required for adequate stocking. By contrast, following a June fire, jack pine should exhibit adequate stand stocking with all but the lowest $\left(5 \mathrm{~m}^{2} / \mathrm{ha}\right)$ pre-fire basal area given a good-seedbed proportion of $27 \%$ (Fig. 2c). Conversely, following an August fire the minimum required basal area increases to $15 \mathrm{~m}^{2} /$ ha (Fig. 2d). Since jack pine releases seeds quickly following fire, a lateseason fire results in significantly more non-abscised seeds in the aerial seedbank, which will be removed by operations as compared to that from an early season fire with a similar salvage date (Greene et al. 2013, Splawinski et al. 2014). In addition, the first summer cohort for both species will have significantly less time to establish following a late season fire-one month for an August fire compared to three months for a June fire (Splawinski et al. 2014). Once again, as mentioned earlier for burned intact stands, this may be offset by the possibility of greater proportions of favorable seedbeds created by late-season fires.

The good-seedbed proportion needed to obtain adequate stand stocking for burned intact black spruce following a June fire is similar to that of $100 \%$ salvaged jack pine with the same fire date under the full range of basal areas. This illustrates the advantage of possessing a rapid post-fire abscission schedule, as is the case for jack pine; more seeds are abscised prior to salvage and fewer are subjected to predation by granivores.

Salvaged stands (Fig. 1c, 1d; 2c, 2d) show more constrained regeneration than intact stands (Fig. 1a, 1b;2a, 2b) for two reasons. First, black spruce is much more deleteriously affected by salvage than is pine because a far higher proportion of its seeds have not yet abscised by the time salvage occurs (Splawinski et al. 2014). While there are a large number of reasons that forest companies prefer to begin salvaging as quickly as tertiary roads can be constructed, nonetheless early salvage curtails the regeneration of species that abscise their seeds slowly over many years (St-Germain and Greene 2009). Secondly, the harvesting equipment will trample about $30 \%$ of already established germinants from the first summer cohort (Greene et al. 2006).

The natural regeneration assessment tool presented in Fig. 3 and Fig. 4 can be used by foresters in the North American boreal forest as laminated guides for post-fire evaluation of the percentage of the burned area that will require planting. Basal area can be taken from inventories. While seed source strength (i.e., basal area) also could be measured via a prism, the field survey is primarily intended to provide a quantification of the seedbeds; this can easily be accomplished through the employment of a line transect following a simplified approach of Splawinski et al. (2014) (i.e., one randomly oriented transect, 25 metres in length, with seedbed type identified every $50 \mathrm{~cm}$ ). A proxy for seedbed quality, perhaps obtained from remotely sensed data, would obviate the need for fieldwork, but this has not yet been attempted by researchers. Estimates of fire severity based on 

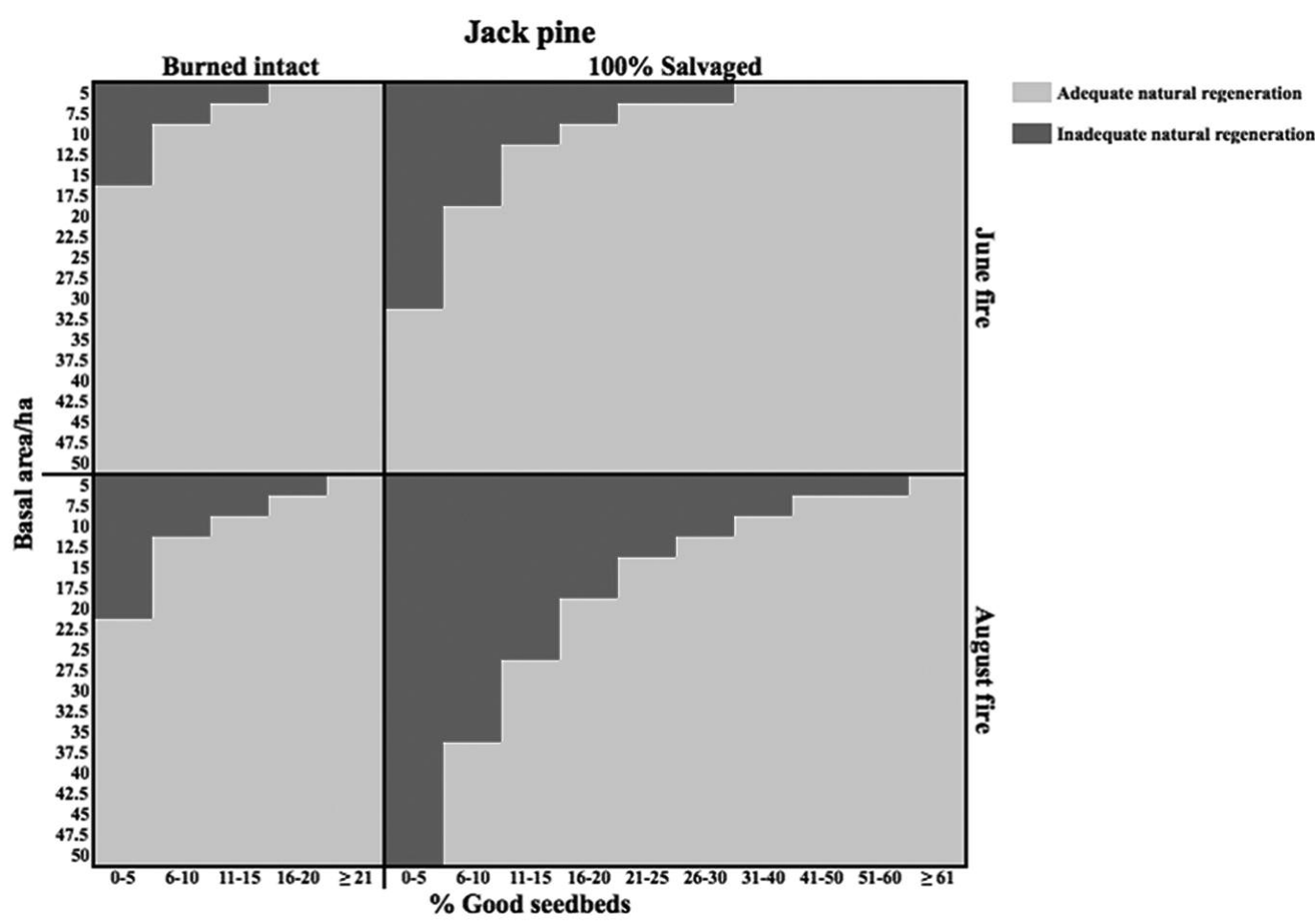

Fig. 4. Simulated jack pine natural regeneration assessment tool illustrating percent of good seedbeds needed to obtain the adequate stand stocking threshold of one seedling $/ \mathrm{m}^{2}$ for every increment of basal area, under both scenarios and fire dates.

the percentage of trees immediately killed by the burn are not well-correlated with measures of seedbed quality (e.g., residual organic layer depth); indeed, most partially killed trees die within two years following fire (Angers et al. 2011).

The sensitivity analysis indicated the model was most sensitive to seed mortality resulting from the passage of the flaming front and the post-fire granivory rate. Therefore we suggest that this tool be applied only to stands exhibiting $100 \%$ tree mortality and subjected to moderate to high severity fires. Extreme fire severity may greatly reduce seed viability, even in the well-protected cones of jack pine (Pinno et al. 2013). Additionally, due to limited data on post-fire granivory rates, actual fire-wide values may differ from our expected values (including the fixed lethal proportion). If this is the case, then the user should make use of the original model available from the author to adjust the predation parameters.

The potential error associated with predictions made in the tools (Fig. 3, Fig. 4) is moderate, based on the $\mathrm{r}^{2}$ values (non-adjusted) obtained from power law regressions for observed versus simulated seedling densities from Splawinski et al. (2014) (Table 1). Their results indicated a variable chance of error $\left(1-\mathrm{r}^{2}\right)$ depending on the fire that was examined; the Lebel-sur-Quevillion fire exhibited little chance of error $\left(r^{2}=0.920\right)$, the Val Paradis fire exhibited a large chance of error $\left(r^{2}=0.000\right.$ to 0.423$)$, and the Muskeg fire exhibited a moderate chance of error $\left(\mathrm{r}^{2}=0.498\right.$ to 0.567$)$.

Unexplained variation in seedling densities observed by Splawinski et al. (2014) was explained by five factors: seed mortality resulting from the passage of the flaming front, the post-fire granivory rate, the estimation of seed production based on pre-fire basal area, first-summer age-specific survivorship of seedlings due to variation in precipitation, and estimation of seedling survivorship based on the grouping of seedbed types and on-site factors (Splawinski et al. 2014).

Although a moderate prediction error exists in the tools themselves, we believe that they provide foresters with a novel and important method for assessing post-fire and postsalvage natural regeneration densities, for planning operations and for estimating the cost of future interventions. We do not suggest that they replace conventional seedling surveys at this time, but be employed together in order to assess their validity and avoid potential consequences of erroneous decisions.

Future research should therefore focus on evaluating the applicability and success of this tool in estimating post-fire and post-salvage regeneration potential. Additionally, further data can be gathered on poorly understood parameters (i.e., post-fire granivory rates, effect of fire severity on seed mortality, and post-fire seedbed proportions). This knowledge can then be used to improve the current assessment tools, as well as the main model.

While the modelling approach adopted in Splawinski et al. (2014) can be applied to any species with an aerial seedbank, we hesitate to suggest applying the results encapsulated here to any other species except perhaps serotinous populations of lodgepole pine (Pinus contorta Dougl. ex Lourd. var. latifolia Engelm.) in the western mountains of North America. This species is closely related to jack pine and has a similar seed mass (and thus expected juvenile survivorship). 


\section{Conclusion}

This operational tool provides a novel approach for managers and foresters to quickly assess reforestation needs following fire and salvage at the stand level. Rapid planning of both salvage operations and planting application will improve both efficiency and response time, thereby increasing the sustainability of this resource while minimizing operational costs. Evaluation can also be used to suggest which sites should be given ameliorative prescriptions such as partial cutting of burned black spruce or direct seeding (Greene et al. 2006, Splawinski et al. 2014).

\section{Acknowledgements}

Funding was provided by the following: NSERC RDC, Chaire CRSNG industrielle en aménagement forestier durable, FQRNT BMP scholarship, and Resolute Forest Products.

\section{References}

Angers, V.A., S. Gauthier, P. Drapeau, K. Jayen and Y. Bergeron. 2011. Tree mortality and snag dynamics in North American boreal tree species after a wildfire: A long-term study. Int. J. Wildland Fire 20: 751-763.

Blouin, J. and J.-P. Berger. 2005. Guide de reconnaissance des types écologiques de la région écologique $6 \mathrm{a}$ - Plaine du lac Matagami et $6 \mathrm{~b}$ - Plaine de la baie de Rupert, ministère des Ressources naturelles et de la Faune, Direction des inventaires forestiers, Division de la classification écologique et productivité des stations.

Charron, I. and D.F. Greene. 2002. Post-wildfire seedbeds and tree establishment in the southern mixedwood boreal forest. Can. J. For. Res. 32: 1607-1615.

De Groot, W.J., P.M. Bothwell, S.W. Taylor, B.M. Wotton, B.J. Stocks and M.E. Alexander. 2004. Jack pine regeneration and crown fires. Can. J. For. Res. 34: 1634-1641.

Enright, N.J., R. Marsula, B.B. Lamont and C. Wissel. 1998. The ecological significance of canopy seed storage in fire-prone environments: A model for resprouting shrubs. J. Ecol. 86: 960-73.

Greene, D.F. and E.A. Johnson. 1998. Seed mass and early survivorship of tree species in upland clearings and shelterwoods. Can. J. For. Res. 28: 1307-1316.

Greene, D.F. and E.A. Johnson. 1999. Modelling recruitment of Populus tremuloides, Pinus banksiana, and Picea mariana following fire in the mixedwood boreal forest of central Saskatchewan. Can. J. For. Res. 29: 462-473.

Greene, D.F., T.B. Splawinski, S. Gauthier and Y. Bergeron. 2013. Seed abscission schedules and the timing of post-fire salvage of Picea mariana and Pinus banksiana. For. Ecol. Manage. 303:20-24. Greene, D.F., S. Gauthier, J. Noël, M. Rousseau and Y. Bergeron. 2006. A field experiment to determine the effect of post-fire salvage on seedbeds and tree regeneration. Front. Ecol. Environ. 4: 69-74.

Greene, D.F., J.C. Zasada, L. Sirois, D. Kneeshaw, H. Morin, I. Charron and M.-J. Simard. 1999. A review of the regeneration dynamics of North American boreal forest tree species. Can. J. For. Res. 29: 824-839.

Greene, D.F., D.D. Kneeshaw, C. Messier, V. Lieffers, D. Cormier, R. Doucet, K.D. Coates, A. Groot, G. Grover and C. Calogeropoulos. 2002. Modelling silvicultural alternatives for conifer regeneration in boreal mixedwood stands (aspen/white spruce/balsam fir). Forest. Chron. 78: 281-295.
Greene, D. F., S. E. MacDonald, S. Haeussler, J. N. Domenicano, K. Jayen, I. Charron, S. Gauthier, S. Hunt, E. T. Gielau, Y. Bergeron and L. Swift. 2007. The reduction of organic-layer depth by wildfire in the North American boreal forest and its effect on tree recruitment by seed. Can. J. For. Res. 37:1012-1023.

Johnstone, J.F., L. Boby, E. Tissier, M. Mack, D. Verbyla and X. Walker. 2009. Post-fire seed rain of black spruce, a semiserotinous conifer, in forests of interior Alaska. Can. J. For. Res. 39: 1575-1588. Kasischke, E.S., K.P. O’Neill, N.H. French and L.L. BourgeauChavez. 2000a. Controls on patterns of biomass burning in Alaskan boreal forests. In: Fire, Climate Change, and Carbon Cycling in the Boreal Forest. Springer New York. pp. 173-196.

Kasischke, E.S., N.H. French, K.P. O’Neill, D.D. Richter, L.L. Bourgeau-Chavez and P.A. Harrell. 2000b. Influence of fire on long-term patterns of forest succession in Alaskan boreal forests. In: Fire, Climate Change, and Carbon Cycling in the Boreal Forest. Springer New York. pp. 214-235.

Lamont, B.B., D.C.L. Maitre, R.M. Cowling and N.J. Enright. 1991. Canopy seed storage in woody plants. Bot. Rev. 57: 277-317. Lavoie, M., D. Paré and Y. Bergeron. 2007. Relationships between microsite type and the growth and nutrition of young black spruce on post-disturbed lowland black spruce sites in eastern Canada. Can. J. For. Res. 37: 62-73.

Lecomte, N., M. Simard and Y. Bergeron. 2006. Effects of fire severity and initial tree composition on stand structural development in the coniferous boreal forest of northwestern Québec, Canada. Ecoscience 13: 152-163.

Miyanishi, K. 2001. Duff consumption. In: Forest Fires: Behaviors and Ecological Effects. Edited by E.A. Johnson and K. Miyanishi. Academic Press, San Diego. pp. 437-470.

Miyanishi, K. and E.A. Johnson. 2002. Process and patterns of duff consumption in the mixedwood boreal forest. Can. J. For. Res. 32: 1285-1295.

Pinno, B. D., R.C. Errington and D.K. Thompson. 2013. Young jack pine and high severity fire combine to create potentially expansive areas of understocked forest. For. Ecol. Manage. 310: 517-522.

St-Germain, M. and D.F. Greene. 2009. Salvage logging in the boreal and cordilleran forests of Canada: Integrating industrial and ecological concerns in management plans. Forest. Chron. 85: 120-134.

Splawinski, T.B., D.F. Greene and S. Gauthier. 2014. A model of the post-fire recruitment of Picea mariana and Pinus banksiana as a function of salvage timing and intensity. Ecol. Mod. 282: 35-43.

Stocks, B. J., J.A. Mason, J.B. Todd, E.M. Bosch, B.M. Wotton, B.D. Amiro, M.D. Flannigan, K.G. Hirsch, K.A. Logan, D.L. Martell and W.R. Skinner. 2002. Large forest fires in Canada, 1959-1997. J. Geophy. Res.: Atmospheres (1984-2012), 107(D1), FFR 5-1-FFR 5-12.

Veilleux-Nolin, M. and S. Payette. 2012. Influence of recent fire season and severity on black spruce regeneration in spruce-moss forests of Quebec, Canada. Can. J. For. Res. 42: 1316-1327.

Zhang, S. Y., G. Chauret, H.Q. Ren and R. Desjardins. 2002. Impact of initial spacing on plantation black spruce lumber grade yield, bending properties, and MSR yield. Wood and Fiber Sci. 34: 460-475. 